\title{
Sterols from the fruit barks of Coelocaryon klainei Pierre ex Heckel (Myristicaceae)
}

Ouayogode Aminata Akoubet ${ }^{1}$, Adiko N'dri Marcelline ${ }^{1}$, ${ }^{*}$ Kablan Ahmont Landry Claude $23,4,5$, Aka Any-Grah Sandrine ${ }^{3}$, Coulibali Siomenan ${ }^{4}$, Adjougoua Atoli Léopold ${ }^{1}$, Kodjo Charles Guillaume5, ${ }^{5,6}$ Effo Kouakou Etienne ${ }^{7}$, Konan Dibi Jacques ${ }^{4}$ Kablan Richmond Jean-François ${ }^{8}$, Zialé Edwige Alette ${ }^{5}$, Attioua Koffi Barthélemy ${ }^{4}$ and Koné Bamba Diénéba ${ }^{1}$

${ }^{1}$ Laboratoire de Pharmacognosie, Botanique, Biologie végétale et Cryptogamie, UFR des Sciences Pharmaceutiques et Biologiques, Université Félix Houphouët-Boigny, 22 BP 714 Abidjan 22, Côte d'Ivoire

${ }^{2}$ UFR des Sciences Biologiques, Université Péléforo Gon Coulibaly, BP 1328 Korhogo, Côte d'Ivoire

${ }^{3}$ Laboratoire de pharmacie galénique, cosmétologie et législation, UFR des Sciences Pharmaceutiques et Biologiques, Université Félix Houphouët-Boigny, 22 BP 714 Abidjan 22, Côte d'Ivoire

${ }^{4}$ Laboratoire de Chimie Organique et de Substances Naturelles, UFR SSMT, Université Félix Houphouët-Boigny, 22 BP 582 Abidjan 22, Côte d'Ivoire

${ }^{5}$ Laboratoire de Chimie BioOrganique et de Substances Naturelles, Université Nangui Abrogoua, UFR-SFA, 02 B.P. 801 Abidjan 02, Côte d'Ivoire

${ }^{6}$ Laboratoire de Thermodynamique et Physicochimie du milieu, Université Nangui Abrogoua, UFR-SFA, 02 B.P. 801 Abidjan 02, Côte d'Ivoire

${ }^{7}$ Département de Pharmacologie et de pharmacie clinique, UFR Sciences Pharmaceutiques et Biologiques, Université Félix HouphouëtBoigny, 22 BP 714 Abidjan 22, Côte d'Ivoire

${ }^{8}$ Laboratoire de Cristallographie et Physique Moléculaire, UFR SSMT, Université Félix Houphouët-Boigny, 01 BP V34 Abidjan 01, Côte d'Ivoire

\section{ABSTRACT}

Two sterols namely $\beta$-sitosterol (1) and stigmasterol (2) were isolated from methanolic extract of the fruit barks of Coelocaryon klainei Pierre ex Heckel (Myristicaceae). They were isolated for the first time from this species. It is the first isolation of compounds in this genus Coelocaryon. The structures were elucidated on the basis of one and two-dimensional NMR, SM, IR and UV.

Key Words: Coelocaryon klainei, Myristicaceae, $\beta$-sitosterol and stigmasterol.

\section{INTRODUCTION}

The genus Coelocaryon (Myristicaceae) comprises 4 recognized species (Coelocaryon botryoides Vermoesen, Coelocaryon oxycarpum Stapf, Coelocaryon preussii Warb., Coelocaryon sphaerocarpum Fouilloy). The genus Coelocaryon is used in traditional medicine to treat various diseases. Coelocaryon oxycarpum stems are taken as purgative. The leaves and the seeds of Coelocaryon sphaerocarpum are used to treat somnolence. Coelocaryon klainei is the most known and used. This species is a tree that grows $30 \mathrm{~m}$ in height (Lemmens et al., 2012). You can find it in Africa (Côte d'Ivoire, Bénin, Nigeria, Centrafrique, Gabon and R.D.C) (Fouilloy, 1965; Fouilloy, 1972; Normand, 1993; Foahom, 2002; Christy et al., 2003; Akoègninou et al., 2005; Hawthorne, 2006; Tchouya et al., 2015). The wood is very durable and is commonly harvested, mainly for trade. The tree produces wood, marketed as "ekoune" or "ekun", which is suitable for joinery (Lemmens et al., 2012). In Côte d'Ivoire the seeds are used to treat diabetes and hypertension. Their stem barks are used in the treatment of hemorrhoids, dysentery (Onanga et al., 1999), diarrhea and venereal diseases. This species is poorly studied so far. So it was important to investigate the chemistry of Coelocaryon. There is only one chemical study on Coelocaryon klainei

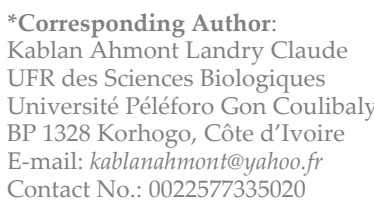

Pierre ex Heckel published, reporting the presence of polyphenols, tannins, flavonoids, sterols/triterpenes, coumarins, saponosides and sugars from the leaves and the barks (Tchouya et al., 2015). We report here, the isolation and characterization of two known sterols from the fruit barks of Coelocaryon klainei.

\section{MATERIALS AND METHODS}

The NMR spectra were recorded on a Brüker Advance-300 operating at $300 \mathrm{MHz}$, using TMS as internal standard. Chemical shifts were quoted in $d$ ppm and coupling constant $J$ was measured in Hertz $(\mathrm{Hz})$. One-dimensional ${ }^{1} \mathrm{H}$ and ${ }^{13} \mathrm{C}$ spectra were acquired under standard conditions. Currently, ${ }^{1} \mathrm{H}-{ }^{1} \mathrm{H}$ homonuclear (COSY, NOESY) and ${ }^{1} \mathrm{H}-$ ${ }^{13} \mathrm{C}$ heteronuclear (HSQC, HMBC) correlation techniques were routinely applied in field of constitutional analysis. These techniques were recorded on a Brücker Avance-400 operating at $400 \mathrm{MHz}$. Column chromatography was performed on silica gel (Kieselgel 60, particle size 0.040-0.063 $\mathrm{mm}$ ) and Sephadex ${ }^{\circledR}$ LH-20. TLC was run on silica gel precoated glass plates (Merck silica gel $60 \mathrm{~F}_{254}$ ). Spots were detected by spraying with phosphomolibdic acid. This operation was followed by a heating. ESIMS Mass spectra were obtained with ITQ 900 spectrometer using an Agilent DB-5HT $(30 \times 0.32 \times 0.1)$ column. IR spectra were recorded with a PerkinElmer type 257 spectrometer. 


\section{Plant material}

The fruit barks of Coelocaryon klainei were collected in June 2015 in Abidjan (South of Côte d'Ivoire). They were identified by Pr. Ipou Ipou Joseph (Centre National de Floristique- Université Félix Houphouët-Boigny). A voucher specimen $\left(\mathrm{n}^{\circ}\right.$ CK-AKOUBET-Abidjan2015-1) is deposited at the Herbarium of the Botanic Laboratory (Université Félix Houphouët- Boigny).

\section{Isolation}

Air-dried pulverized fruit barks of Coelocaryon klainei (1500 g) were three times defatted with cyclohexane and successively extracted with $\mathrm{CH}_{2} \mathrm{Cl}_{2}$, AcOEt and $\mathrm{MeOH}$. The collected extracts were evaporated under reduced pressure to yield $9.8 \mathrm{~g}$ of cyclohexane extract, $5.3 \mathrm{~g}$ of $\mathrm{CH}_{2} \mathrm{Cl}_{2}$ extract, $3.8 \mathrm{~g}$ of AcOEt extract and $1.9 \mathrm{~g}$ of $\mathrm{MeOH}$ extract. The cyclohexane extract was chromatographed over silica gel column chromatography, eluting with cyclohexane-dichloromethane gradient systems to give eight fractions (F1 to F-8). Fraction F-6 was purified using repeated Sephadex ${ }^{\circledR} \mathrm{LH}-20 \quad\left[\mathrm{MeOH} / \mathrm{CH}_{2} \mathrm{Cl}_{2} \quad(1 / 2)\right]$ and column chromatography on silica gel, to yield $4.9 \mathrm{mg}$ of compound $\mathbf{1}$ and $5.6 \mathrm{mg}$ of compound $\mathbf{2}$ (Fig. 1). The structures of these compounds (Fig. 1) were established according to their spectral data (NMR, IR and MS).

\section{Identification of compounds 1 and 2}

$\boldsymbol{\beta}$-Sitosterol (1): colourless crystalline; ${ }^{1} \mathrm{H}$ and ${ }^{13} \mathrm{C}$ NMR $(400 \mathrm{MHz})$ data in table 1; IR $\left(\mathrm{CHCl}_{3}\right): v_{\max }\left(\mathrm{cm}^{-1}\right)=3570$, 2864, 1585, 1016, 609; UV $\left(\mathrm{CHCl}_{3}\right): \lambda_{\max }(\mathrm{nm})=220$; ESI-MS $(\mathrm{m} / \mathrm{z}): 415[\mathrm{M}+\mathrm{H}]^{+}$(molecular formula $\left.\mathrm{C}_{29} \mathrm{H}_{50} \mathrm{O}\right)$.

Stigmasterol (2): white amorphous solid; ${ }^{1} \mathrm{H}$ and ${ }^{13} \mathrm{C}$ NMR $(400 \mathrm{MHz})$ data in table 1; IR $\left(\mathrm{CHCl}_{3}\right): v_{\max }\left(\mathrm{cm}^{-1}\right)=3428$, 1192, 699; UV $\left(\mathrm{CHCl}_{3}\right): \lambda_{\max }(\mathrm{nm})=257$; ESI-MS $(\mathrm{m} / \mathrm{z}): 413$ $[\mathrm{M}+\mathrm{H}]^{+}$(molecular formula $\mathrm{C}_{29} \mathrm{H}_{48} \mathrm{O}$ ).

\section{RESULTS AND DISCUSSION}

Compound (1) was isolated as a colourless crystalline. The UV spectrum of this compound showed maximum absorption bands at $\lambda_{\max }: 220 \mathrm{~nm}$. Its MS spectrum shown the pseudo-molecular ion fragment $[\mathrm{M}+\mathrm{H}]^{+}$at $(\mathrm{m} / \mathrm{z})=415$. So, it molecular formula was deduced to be $\mathrm{C}_{29} \mathrm{H}_{50} \mathrm{O}$. The IR absorption band at $3570 \mathrm{~cm}^{-1}$ was attributed to the hydroxyl group and the broad band $\left(1585 \mathrm{~cm}^{-1}\right)$ indicates the presence of $(C=C)$ stretching. These absorption frequencies resemble the absorption frequencies observed for $\beta$-sitosterol as resembled data published by (Arjun et al., 2010; Bulama et al., 2015).
The ${ }^{1} \mathrm{H}$ and ${ }^{13} \mathrm{C}$ NMR spectra (Table 1) allowed the identification of the steroidal skeleton. The typical H-6 of the steroidal skeleton was evident as a multiplet at $\delta_{\mathrm{H}} 5.30$ $\mathrm{ppm}$ that integrated for one proton. The spectrum further revealed signals at $\delta_{\mathrm{H}} 0.92,0.84,0.82$ and $0.80 \mathrm{ppm}$ ( $3 \mathrm{H}$ each) assignable to four methyl group at C-19, C-24, C-26, C-27 respectively. This compound is having six methyl, eleven methylene and three quaternary carbons with a hydroxyl group. The above spectral features are in closed agreement to those observed for $\beta$ - sitosterol according to (Escudero et al., 1985; Manoharan et al., 2005).

The ${ }^{13} \mathrm{C}$-NMR has shown recognizable signals 140.7 and $121.6 \mathrm{ppm}$, which are assigned C-5 and C-6 double bonds respectively. The carbon peak at $\delta C 71.9$ is in the "al-

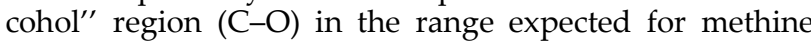
carbon ( $\mathrm{CH}-\mathrm{O})$, so it was assigned to $\mathrm{C}-3$. HMBC correlation of the proton, $\mathrm{H}-3$ (3.53 ppm), to carbon C-5 ( $\delta \mathrm{c} 140.7)$ and to proton $\mathrm{H}-3$ to the carbon at $\delta c 37.4 \mathrm{ppm}(\mathrm{C}-1)$ confirmed the hydroxyl position as being located on C-3.

Spectra show twenty-nine carbon signal including six methine groups, eleven methylene groups, six methyl groups and three quaternary carbons. The alkene carbons appeared at $\delta 140.7$ and $121.6 \mathrm{ppm}$. Compound 1 was identified as $\beta$-sitosterol. Its physical and spectral data are consistent to those reported by literature (Manoharan et al., 2005; Anjoo et al., 2011).

Compound (2) was obtained as white amorphous solid. The UV $\lambda_{\max }$ value of compound 2 was $257 \mathrm{~nm}$. Mass spectrum of isolated compound 2 showed pseudo-molecular ion at $m / z[\mathrm{M}+\mathrm{H}]^{+}$peak at $m / z 413$ which corresponds to the molecular formula $\mathrm{C}_{29} \mathrm{H}_{48} \mathrm{O}$ (fig. 1). IR absorption bands at 3428 and $699 \mathrm{~cm}^{-1}$ were due to the presence of hydroxyl and alkenes respectively.

The ${ }^{1} \mathrm{H}$ NMR spectrum (Table 1) exhibited characteristic signals of protons at $\delta$ н 3.50 (H-3) appeared as a triplet of a double doublet $(t d d)$ and at $\delta_{\mathrm{H}} 5.29$ (H-6, $m$ ) for an olefinic proton. Two olefenic protons appeared downfield at $\delta(4.97, m)$ and $(5.13, m)$. Six methyls protons also appeared at $\delta 0.90, \delta 0.83, \delta 0.80, \delta 0.79, \delta 0.72$ and $\delta 1.02 \mathrm{ppm}(3 \mathrm{H}$ each, $\mathrm{s}, \mathrm{CH}_{3}$ ) (Table 1). These attributions were done on the basis of its HSQC experiment data.

The ${ }^{13} \mathrm{C}$ NMR has shown recognizable signal at $\delta c$ 141.1 and $121.6 \mathrm{ppm}$, which corresponds to double bond at C-5 and C-6 double bonds respectively as well as it also represents signals at 138.4 and $129.4 \mathrm{ppm}$, which shows one more double bond in between $\mathrm{C}-20$ and $\mathrm{C}-21$. The $\delta$ value at $72.0 \mathrm{ppm}$ is due to $C-3 \beta$-hydroxyl group. The signal at $\delta$ 29.5 and $\delta 19.7 \mathrm{ppm}$ corresponds to angular carbon atom at C-25 and C-27 respectively (table 1 ).
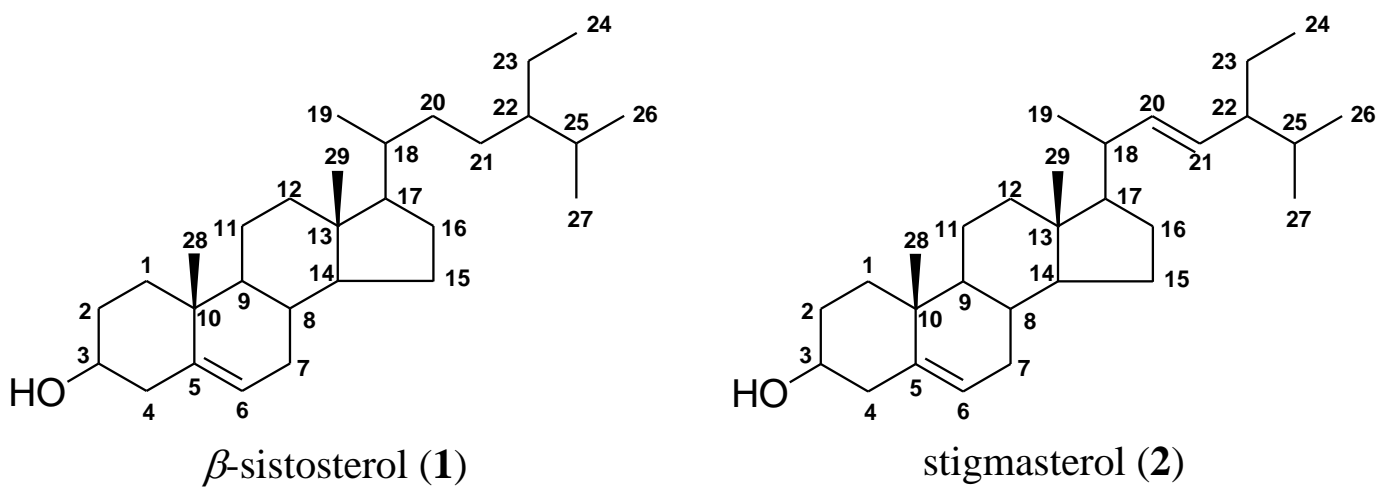

Figure 1: Structures of compounds $\underline{1}$ and $\underline{2}$. 


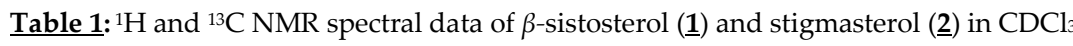

\begin{tabular}{|c|c|c|c|c|}
\hline \multirow{2}{*}{ Position } & \multicolumn{2}{|r|}{1} & \multicolumn{2}{|r|}{2} \\
\hline & ${ }^{13} \mathrm{C}$ & ${ }^{1} \mathbf{H}$ & ${ }^{13} \mathrm{C}$ & ${ }^{1} \mathbf{H}$ \\
\hline 1 & 37.4 & & 37.5 & \\
\hline 2 & 31.8 & & 32.0 & \\
\hline 3 & 71.9 & $3.53(t d d, 1 \mathrm{H}, \mathrm{J}=4.4,4.1,3.9)$ & 72.0 & $3.50(t d d, 1 \mathrm{H}, \mathrm{J}=4.4,4.1,3.9)$ \\
\hline 4 & 42.3 & & 42.3 & \\
\hline 5 & 140.7 & & 141.1 & \\
\hline 6 & 121.6 & $5.30(m, 1 \mathrm{H})$ & 121.6 & $5.29(m, 1 \mathrm{H})$ \\
\hline 7 & 32.0 & & 31.7 & \\
\hline 8 & 32.0 & & 31.7 & \\
\hline 9 & 50.1 & & 50.1 & \\
\hline 10 & 36.4 & & 36.5 & \\
\hline 11 & 21.2 & & 21.4 & \\
\hline 12 & 39.7 & & 39.7 & \\
\hline 13 & 42.4 & & 42.2 & \\
\hline 14 & 56.9 & & 56.4 & \\
\hline 15 & 26.2 & & 42.1 & \\
\hline 16 & 28.4 & & 29.1 & \\
\hline 17 & 56.2 & & 56.0 & \\
\hline 18 & 36.1 & & 40.5 & \\
\hline 19 & 19.0 & $0.92(d, 3 \mathrm{H}, \mathrm{J}=6.5 \mathrm{~Hz})$ & 21.6 & $0.90(d, 3 \mathrm{H}, \mathrm{J}=6.1 \mathrm{~Hz})$ \\
\hline 20 & 34.0 & & 138.4 & $4.97(m, 1 \mathrm{H})$ \\
\hline 21 & 26.1 & & 129.4 & $5.13(m, 1 \mathrm{H})$ \\
\hline 22 & 45.9 & & 45.9 & \\
\hline 23 & 23.1 & & 25.2 & \\
\hline 24 & 12.2 & $0.84(d, 3 \mathrm{H}, \mathrm{J}=7.3 \mathrm{~Hz})$ & 12.1 & $0.83(d, 3 \mathrm{H}, \mathrm{J}=7.3 \mathrm{~Hz})$ \\
\hline 25 & 29.3 & & 29.5 & \\
\hline 26 & 20.0 & $0.82(d, 3 \mathrm{H}, \mathrm{J}=6.3 \mathrm{~Hz})$ & 20.1 & $0.80(d, 3 \mathrm{H}, \mathrm{J}=6.7 \mathrm{~Hz})$ \\
\hline 27 & 19.5 & $0.80(d, 3 \mathrm{H}, \mathrm{J}=6.3 \mathrm{~Hz})$ & 19.7 & $0.79(d, 3 \mathrm{H}, \mathrm{J}=6.6 \mathrm{~Hz})$ \\
\hline 28 & 19.0 & $0.68(s, 3 \mathrm{H})$ & 18.6 & $0.72(s, 3 \mathrm{H})$ \\
\hline 29 & 11.9 & $1.00(s, 3 \mathrm{H})$ & 12.1 & $1.02(s, 3 \mathrm{H})$ \\
\hline
\end{tabular}

The ${ }^{1} \mathrm{H}$ and ${ }^{13} \mathrm{C}$ NMR spectroscopy data (Table 1 ) were similar to those of $\beta$-sitosterol (1), the only difference was the absence of two methylene groups and the presence of two methine groups for compound 2 . The position of the two methines was established by HMBC correlations of $\mathrm{H}$ $24\left(\delta_{\mathrm{H}} 0.83\right)$ to $\mathrm{C}-21(\delta \mathrm{c} 129.4)$ and $\mathrm{H}-20\left(\delta_{\mathrm{H}} 4.97\right)$ to $\mathrm{C}-22(\delta \mathrm{C}$ 45.9). From the above observations, isolated compound was found to be stigmasterol (2) (Anjoo, et al., 2011; Venkata et al., 2012; Luhata et al., 2015).

\section{CONCLUSION}

The phytochemical examination of Coelocaryon klainei belonging to the family (Myristicaceae) fruit barks was effectively carried out. From these chemical and spectral evidences compound 1 and compound 2 were confirmed as respectively $\beta$-Sitosterol (1) and Stigmasterol (2) (fig. 1). The complete ${ }^{1} \mathrm{H}$ and ${ }^{13} \mathrm{C}$ NMR spectral assignments of the two isolated compounds were made based on COSY, HSQC, HMBC, and ESI-MS spectroscopic data. Their structures are in agreement with those reported by literature.

\section{ACKNOWLEDGEMENT}

We wish to thank the Ministry of Research of the Republic of Côte d'Ivoire for the financial support.

\section{REFERENCES}

Akoègninou, A., Van der Burg, W.J., Van der Maesen, L.J.G. (2006). Flore analytique du Bénin. Backhuys Publishers, Leiden, Netherlands. pp.1034.

Anjoo Kamboj, Ajay Kumar Saluja. (2011). Isolation of stigmasterol and $\beta$ sitosterol from petroleum ether extract of aerial parts of Ageratum conyzoides (Asteraceae). International Journal of Pharmacy and Pharmaceutical Sciences, 3, 1, 94-96.

Arjun, P., Jha, S., Murthy, P.N., Manik, M., and Sharone, A. (2010). Isolation and Characterization of $\beta$-Sitosterol from the leaves of Hygrophila spinosa. International Journal of Pharma Science \& Research, 1, 2, 95-100.

Bulama J.S., Dangoggo S.M., Mathias S.N. (2015). Isolation and Characterization of Beta-Sitosterol from ethyl acetate extract of root bark of Terminalia glaucescens. International Journal of Scientific and Research Publications, 5, 2250-3153.

Christy, P., Jaffré, R., Ntougou, O., Wilks, C. (2003). La forêt et la filière bois au Gabon. Projet Aménagement Forestier et Environnement, Libreville, Gabon. pp. 389.

Escudero, J., Lopez, C. Rabanal, R.M., Valverde, S. (1985). Secondary metabolites from Satureja species. New triterpenoid from Satureja acinos. Journal of Natural products, 48, $128-131$. [DOI]

Foahom, B. (2002). Insect pest incidence on timber tree species in natural forest in South Cameroon. Tropenbos-Cameroon Document 12. Tropenbos Cameroon Programme, Kribi, Cameroon. pp. 54.

Fouilloy, R. (1965). Myristicacées. Flore du Gabon. Volume 10. Muséum National d'Histoire Naturelle, Paris, France. pp. 83-101.

Fouilloy, R. (1972). Trois arbres nouveaux d'Afrique tropicale (Laur. Myrist. - Sapind.). Adansonia, ser., 2, 12, 4, 545-555.

Hawthorne, W., Jongkind, C. (2006). Woody plants of western African forests: a guide to the forest trees, shrubs and lianes from Senegal to Ghana. Kew Publishing, Royal Botanic Gardens, Kew, United Kingdom. pp.1023. 
Lemmens, R.H.M.J., Louppe, D., Oteng-Amoako, A.A. (2012). Ressources végétales de l'Afrique tropicale, 7(2). Bois d'œuvre 2. Fondation PROTA, Wageningen, Pays-Bas/CTA, Wageningen, Pays-Bas. pp. 233235.

Luhata, L. P., Munkombwe N. M. (2015). Isolation and Characterisation of Stigmasterol and $\beta$-Sitosterol from Odontonema Strictum (Acanthaceae). Journal of Innovations in Pharmaceuticals and Biological Sciences. 2, 1, 88-95.

Manoharan, K.P., Haut, B.T.K., Yang,D. (2005). Cycloartane types triterpenoids from the rhizomes of Polygonum bistorta. Phytochemistry, 66, 1168 1173. [DOI]

Normand D. (1933). Les Bois de Myristicacées du Gabon. In: Revue de botanique appliquée et d'agriculture coloniale, $13^{\mathrm{e}}$ année, bulletin $\mathrm{n}^{\circ} 143,471$ 479. [DOI]
Onanga, M., Ekouya, U. A., Ouabonzi, A., Itoua G.B. (1999). Ethnobotanical, pharmacological and chemical studies of plants used in the treatment of 'Mwandza' dermatitis. Fitoterapia, 70, 579-585. [DOI]

Tchouya, G. R. F., Souza, A., Tchouankeu, J. C., Yala, J.-F., Boukandou, M., Foundikou, H., Obiang, G. D. N., Boyom, F. F., Mabika, R. M., Menkem, E. Z., Ndinteh, D. T., Lebibi J. (2015). Ethnopharmacological surveys and pharmacological studies of plants used in traditional medicine in the treatment of HIV/AIDS opportunistic diseases in Gabon. Journal of Ethnopharmacology, 162, 306-316. [DOI]

Venkata, S. Prakash, C., Indra P. (2012). Isolation of Stigmasterol and $\beta$-Sitosterol from the dichloromethane extract of Rubus suavissimus. International Current Pharmaceutical Journal, 1, 9, 239-242. [DOI] 